\title{
Fossil woods (Coniferales) from the Baqueró Group (Aptian), Santa Cruz Province, Argentina
}

\author{
EZEQUIEL I. VERA and SILVIA N. CÉSARI
}

CONICET- Museo Argentino de Ciencias Naturales, Av. Ángel Gallardo 470, Buenos Aires, C1405DJR, Argentina

Manuscript received on July 27, 2010; accepted for publication on January 7, 2011

\begin{abstract}
Two new conifer morphospecies represented by a secondary xylem are reported for the Lower Cretaceous Baqueró Group (Santa Cruz Province, Argentina). Agathoxylon sp. is characterized by poorly defined growth rings, predominantly uniseriate pitting in the radial wall of the tracheids, cross fields with 1-6 pits and uniseriate rays. These features are shared with the leafy branches described for the unit as Araucaria grandifolia Feruglio emend. Del Fueyo and Archangelsky. The second taxon, Brachyoxylon sp. cf. B. boureaui, possesses poorly defined growth rings, mixed wood with predominantly uniseriate radial pitting, cross fields with 8-26 pits and uniseriate rays. These taxa represent the first fossil woods described for Baqueroan strata.
\end{abstract}

Key words: Fossil woods, Agathoxylon, Brachyoxylon, Lower Cretaceous, Patagonia, Baqueró Group.

\section{INTRODUCTION}

The Baqueró flora represents one of the most exhaustively studied fossil communities of the Early Cretaceous of Gondwana. The research made since the early twenties of the twentieth century has resulted in an extensive list of taxa, as well as in several biostratigraphical and palaeoecologial studies (see Archangelsky (2003), Del Fueyo et al. (2007), and Limarino et al. (2012) for a detailed review). Most megafloral remains of the unit are preserved as impression fossils, whereas compressions of leaves and branches with preserved cuticles are abundant in some fossiliferous levels.

Conifers of the Baqueró Group are represented by four families (Araucariaceae, Podocarpaceae,

Correspondence to: Ezequiel I. Vera

E-mail: evera@macn.gov.ar
Cupressaceae and Cheirolepidiaceae). Araucarian taxa include sterile branches (Araucaria grandifolia Feruglio emend. Del Fueyo and Archangelsky 2002), branches with fertile structures (Nothopehuen brevis Del Fueyo 1991 and Alkastrobus peltatus Del Fueyo and Archangelsky 2005), isolated ovuliferous scales (Araucarites spp.) and isolated pollen grains (Araucarites, Balmeiopsis, Cyclusphaera) (Archangelsky 2003, Del Fueyo and Archangelsky 2002, Del Fueyo and Archangelsky 2005). On the other hand, the fossil family Cheirolepidiaceae is somewhat less diverse, and is represented by fertile branches included in several species of Tomaxellia and abundant pollen grains of the genus Classopollis (Archangelsky 2003). The most diverse conifer family of the Baqueroan strata is the Podocar- 
paceae, represented by fertile (Apterocladus lanceolatus Archangelsky 1966, Squamastrobus tigrensis Archangelsky and Del Fueyo 1989, Morenoa fertilis Del Fueyo, Archangelsky and Taylor 1990, Trisacocladus tigrensis Archangelsky 1966) and sterile (Podocarpus dubius Archangelsky 1966, Podocarpus? palissyafolia (Berry) Florin) branches, and isolated pollen grains (distributed in the genera Callialasporites, Dacrydiumites, Gamerroites, Microcachrydites, Podocarpidites and Trisaccites) (Archangelsky 2003). Finally, Cupressaceae are represented exclusively by the leafy branch Athrotaxis ungeri Halle emend. Villar de Seoane 1998 (Archangelsky 2003).

Fossil woods have been reported from Baqueroan sediments since the beginning of the field studies in the area (Archangelsky 1967). However, for the time being, no description has been provided in the literature for these remains. In this contribution, several fossil wood specimens collected from several fossiliferous localities are described in detail and referred to the conifer genera Agathoxylon Hartig 1848 sensu Philippe 1995 and Brachyoxylon Hollick and Jeffrey 1909.

The Baqueró Group occurs in the central region of the Santa Cruz Province (Argentina), in the Macizo de Deseado Basin. Deposits included in this Group are mostly continental, consisting of lacustrine and fluvial sediments (Cladera et al. 2002). Cladera et al. (2002) recognize three formational units in this group, named the Anfiteatro de Ticó, Bajo Tigre and Punta del Barco formations. Recently, Limarino et al. (2012) recognized within this Group three depositional sequences, and identified 13 fossiliferous stratigraphic levels. Radiometric ages obtained for these deposits revealed ages of $111.8+/-7.40$ $\mathrm{Ma}$ and $118.56+/-1.40 \mathrm{Ma}$ for the Anfiteatro de Ticó (Corbella, 2001, 2006) and 114.67+/- 0.18 Ma for the Punta del Barco Formation (Césari et al. 2011), placing the deposition of the Baqueró Group during the late Aptian.

\section{MATERIALS AND METHODS}

The studied specimens come from sediments of the Baqueró Group and were collected at four fossiliferous localities: Cerro Testigo (48 $\left.30^{\prime} 35.75^{\prime \prime S} 69^{\circ} 5^{\prime} 47.14^{\prime \prime W}\right)$, Estancia El Verano (48³8'29.40"S 698'5.34"W), Punta del Barco Sur (48 39'30"S 69 7'18"W) and Anfiteatro de Ticó (4830'34.27"S 69¹4'13.44"W) (Fig. 1). For each specimen, the Stratigraphic Level (sensu Limarino et al. 2012) from where it was collected, is given. All the studied specimens are deposited in the Museo Regional Provincial Padre Manuel Jesús Molina, Santa Cruz province, Argentina, under MPM PB catalog numbers.

Specimens consist of silicifications and charcoalifications. Silicifications were thin-sectioned in transverse (TS), longitudinal tangential (LTS) and longitudinal radial(LRS) sections. Silicified specimens were studied under Light Microscopy (Olympus BX51) and Scanning Electronic Microscopy (SEM, Philips XL30 TMP). Charcoalifications were observed exclusively under SEM.

For the generic classification of the studied woods we followed the key for fossil morphogenera proposed by Philippe and Bamford (2008).

Systematic PALAEONTOLOGY

Order Coniferales

Agathoxylon Hartig 1848, sensu Philippe 1995

Type Species: Agathoxylon cordaianum Hartig 1848

The use of the form-genera Agathoxylon Hartig 1848 and Araucarioxylon Kraus (in Schimper 1870) for fossil woods with the anatomy similar to the extant Araucariaceae is long established. However, several views regarding the legitimity of these genera have been published elsewhere. In particular, some authors concluded that these fossil woods should be included in Agathoxylon, leaving Araucarioxylon as 

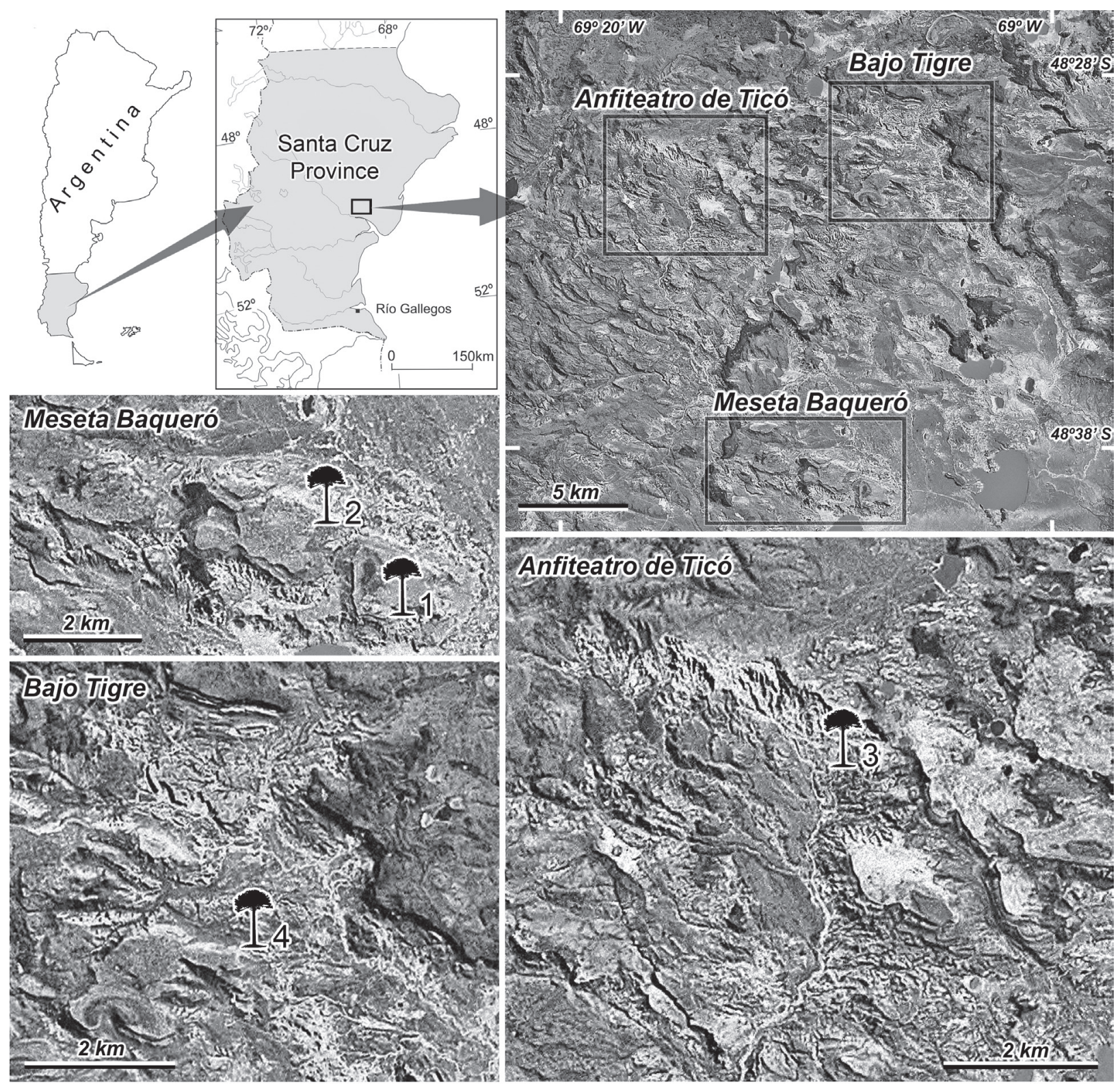

Fig. 1 - Location map showing fossiliferous localities. Locality references: 1. Punta del Barco Sur; 2. Estancia El Verano; 3. Anfiteatro de Ticó; 4. Cerro Testigo.

a junior synonym of Pinites Witham 1833 (Philippe 1993, 1995, Bamford and Philippe 2001, Philippe and Bamford 2008). Although the original diagnosis of the genus Agathoxylon Hartig (Hartig 1848, Philippe and Bamford 2008) includes the presence of axial parenchyma as a diagnostic character (a feature absent in several specimens referred to Agathoxylon), Philippe (1995) reformulated the original diagnosis proposed by Hartig (1848), allowing the inclusion of woods with and without axial parenchyma. We believe this taxonomic decision is adequate since a high number of genera have already been proposed, and erecting another one for including Agathoxylon-like woods without axial parenchyma would lead to a more confuse taxonomy. 

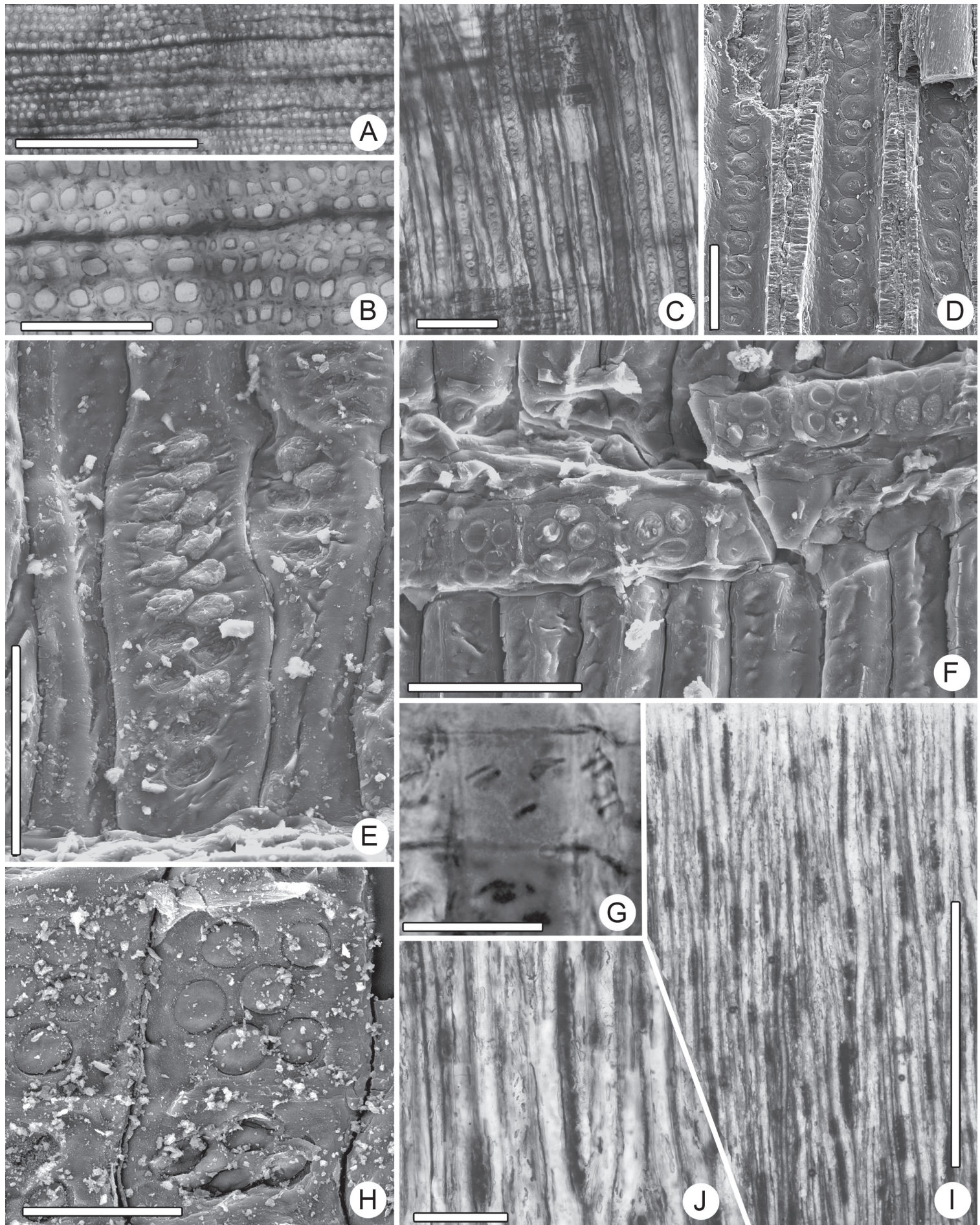

Fig. 2 - Agathoxylon sp. (A) General view of the transverse section (TS) (MPM PB 3178), scale bar = $1 \mathrm{~mm}$. (B) Detail of (A) showing the limit of a growth ring, scale bar $=200 \mu \mathrm{m}$. (C) Tracheids in longitudinal radial section (LRS) (MPM PB 3178), scale bar $=200 \mu \mathrm{m}$. (D) Radial pitting of the tracheids (LRS) (MPM PB 3178), scale bar $=50 \mu \mathrm{m}$. (E) Biseriate radial pitting of the tracheids (LRS) (MPM PB 3178), scale bar $=50 \mu \mathrm{m}$. (F) Cross-field region (LRS) (MPM PB 3178), scale bar $=50 \mu \mathrm{m}$. (G) Detail of cross-field pitting (LRS) (MPM PB 3178), scale bar $=20 \mu \mathrm{m}$. (H) Detail of cross-field pitting (LRS) (MPM PB 3178), scale bar $=50 \mu \mathrm{m}$. (I) Uniseriate rays in longitudinal tangential section (LTS) (MPM PB 3178), scale bar $=1 \mathrm{~mm}$. (J) Detail of uniseriate rays (LTS) (MPM PB 3178), scale bar $=200 \mu \mathrm{m}$. 
Agathoxylon sp.

\section{Reference specimen: MPM PB 3178}

Locality of the reference specimen: Cerro Testigo, Estancia Bajo Tigre, Santa Cruz Province, Argentina.

Horizon of the reference specimen: Punta del Barco Formation, Stratigraphic Level 9.

Additional specimens (localities and stratigraphic horizons): MPM PB 3179 (Estancia El Verano, Santa Cruz Province, Argentina; Anfiteatro de Ticó Formation, Stratigraphic Level 1) and MPM PB 3180 (Punta del Barco Sur, Meseta Baqueró, Santa Cruz Province, Argentina; Punta del Barco Formation, Stratigraphic Level 12).

Age: Early Cretaceous/Aptian

Description: This description is based on three specimens composed exclusively of secondary xylem.

In transverse section, growth rings are indistinct, sometimes with a narrow zone (1-3 cells in width) of late wood. Early wood tracheids are 51 (31-72) $\mu \mathrm{m}$ in diameter, with thick walls $(14$ (7.5-13) $\mu \mathrm{m}$ in thickness) (Fig. 2A, B).

In radial section, tracheids present circular to polygonal bordered pits arranged predominantly in uniseriate rows (Fig. 2C, D). Biseriate pitting pattern is less common, and when present, the pits are arranged alternate to opposite (Fig. 2E). Pits measure $10(6-13) \mu \mathrm{m}$ in diameter, with circular apertures (ca. $3 \mu \mathrm{m}$ in diameter). Cross-field regions are of the araucarioid type and characterized by the presence of 1-6 (mean 3, median 3) circular pits (6.6 (5.8-7.5) $\mu \mathrm{m}$ in diameter) (Fig. 2F-H). Pit apertures are obliquely -oriented, slit like, measuring $4 \mu \mathrm{m}$ in its greater axis.

In tangential section, rays are exclusively uniseriate 1-13 (mean 6, median 7) cells tall (Fig 2I, J). Ray cells are parenchymatic and measure 26 (21-31) $\mu \mathrm{m}$ in height and 20 (17-23) $\mu \mathrm{m}$ in width. Generally, 35 rays per $\mathrm{mm}^{2}$ are observed.

Comparisons: The fossil record of Agathoxylontype wood is extensive, with more than 60 species (and many referred as Agathoxylon sp.) listed by Philippe et al. (2004a) for Gondwana. As previous authors have expressed (e.g. Bamford and Philippe 2001, Poole and Mirzaie Ataabadi 2005), a comprehensive revision of the species referred to this genus is pending. Since such revision exceeds the objectives of the present work, no attempt was made to place the studied specimens in one of the currently recognized species.

Leafy araucarian branches have been previously reported for the Baqueró Group, first by Feruglio (1951) and later by Del Fueyo and Archangelsky (2002), and referred to Araucaria grandifolia Feruglio emend. Del Fueyo and Archangelsky. These specimens, collected in the volcaniclastic strata of the Punta del Barco Formation, have anatomical features similar to the ones present in Agathoxylon sp., such as the presence of uniseriate pitting in the radial walls of the tracheids, uniseriate rays and cross fields with 5-6 pits. Since both taxa were found in the Baqueró Group, it is possible that they may have been originated from a single biological entity.

Affinities: Among extant conifers, Agathoxylontype wood (characterized by the presence of araucarian tracheid pitting and araucarioid cross-field pits) is recorded exclusively in the Araucariaceae (Philippe et al. 2004a). However, Pteridospermales and Cheirolepidiaceae also possessed this type of wood (Philippe et al. 2004a). As pointed above, Agathoxylon sp. and Araucaria grandifolia share many anatomical features, and they may have been part of the same biological species (referable to the Araucariaceae).

Brachyoxylon Hollick and Jeffrey 1909

Type species: Brachyoxylon notabile Hollick and Jeffrey 1909

Protopodocarpoxylon Eckhold includes in its diagnosis the presence of podocarpoid 

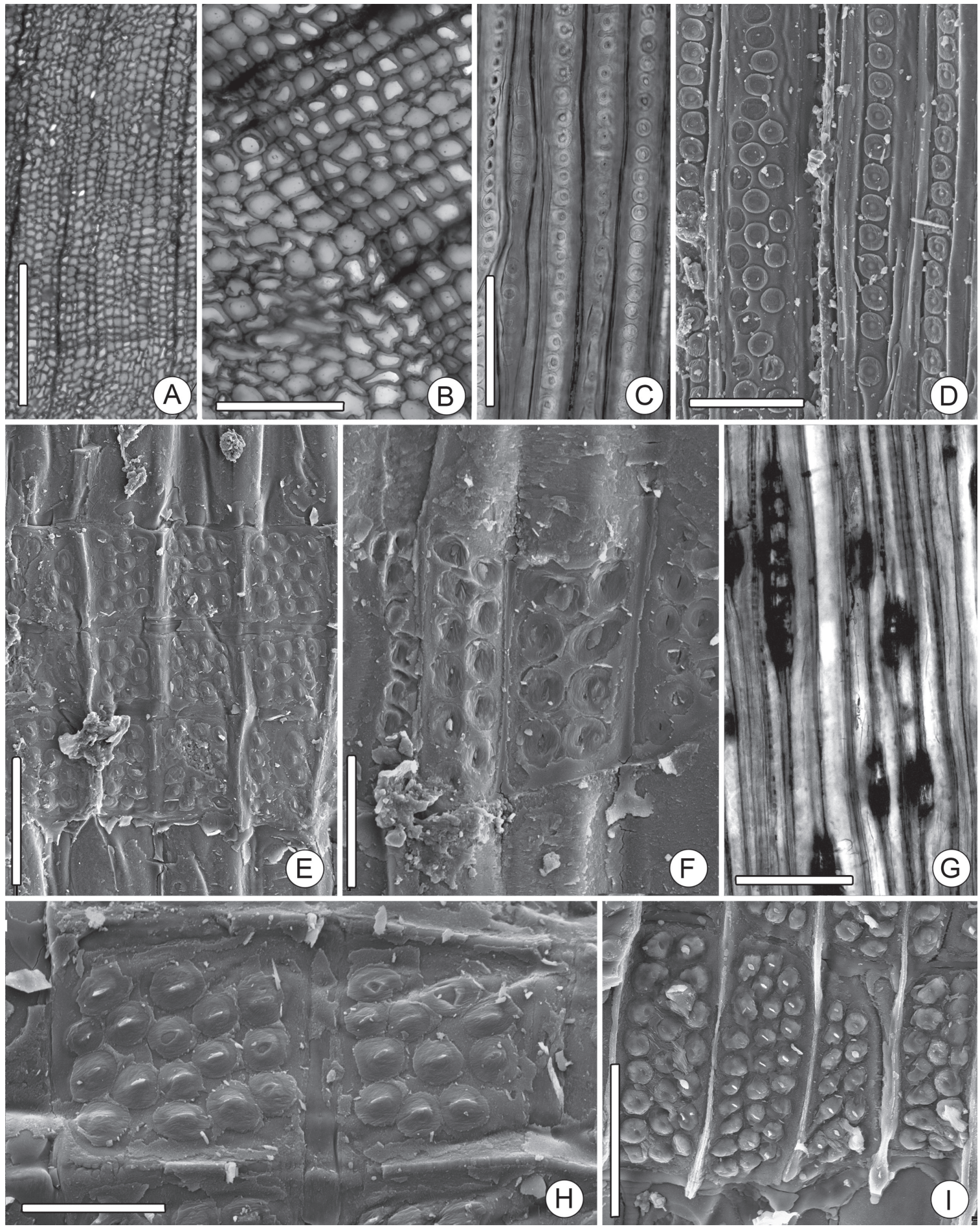

Fig. 3 - Brachyoxylon sp. cf. B. boureaui Serra. (A) General view of the transverse section (TS) (MPM PB 3181), scale bar $=500 \mu \mathrm{m}$. (B) Detail of (A) showing the limit of a growth ring (TS), scale bar $=200 \mu \mathrm{m}$. (C) Tracheids in longitudinal radial section (LRS) (MPM PB 3181), scale bar $=200 \mu \mathrm{m}$. (D) Uniseriate and triseriate pitting in the tracheids (LRS) (MPM PB 3181), scale bar $=100 \mu \mathrm{m}$. (E) Cross-field regions (LRS) (MPM PB 3181), scale bar $=50 \mu \mathrm{m}$. (F) Cross-field regions (LRS) (MPM PB 3181), scale bar $=20 \mu \mathrm{m}$. (G) Uniseriate rays in longitudinal tangential section (LTS) (MPM PB 3181), scale bar $=100 \mu \mathrm{m}$. (H) Detail of (E) showing two cross-field regions (LRS), scale bar $=20 \mu \mathrm{m}$. (I) Cross field regions (LTS) (MPM PB 3184), scale bar $=25 \mu \mathrm{m}$. 
cross fields. However, Protopodocarpoxylon blenvillense, the first species referred to this genus (and thus, it's Type Species), possesses araucarioid cross fields. If this species remained as the type species, this genus should be regarded as a junior synonym of Brachyoxylon (Bamford and Philippe 2001). Recently, Philippe et al. (2002) have proposed a nomina conservanda for the genus Protopodocarpoxylon using as neotype the species Protopodocarpoxylon bedfordense Stopes, which has podocarpoid cross fields. This proposal, accepted by the Committee for Fossil Plants (Skog 2003), is here followed, and the studied specimens are referred to (Brachyoxylon Hollick and Jeffrey 1909).

\section{Brachyoxylon sp. cf. Brachyoxylon boureaui Serra 1966}

\section{Reference specimen: MPM PB 3181}

Locality of the reference specimen: Anfiteatro de Ticó. Santa Cruz Province, Argentina.

Horizon of the reference specimen: Anfiteatro de Ticó Formation, Stratigraphic Level 5.

Additional specimens (localities and stratigraphic horizons): MPM PB 3182, MPM PM 3183, MPM PB 3184 and MPM PB 3185 (Punta del Barco Sur, Meseta Baqueró, Santa Cruz Province, Argentina; Punta del Barco Formation, Stratigraphic Level 12)

Age: Early Cretaceous/Aptian

Description: This description is based on five specimens composed exclusively of a secondary xylem.

In transverse section, growth rings are indistinct, sometimes with a narrow zone (1-3 cells in width) of late wood (Fig. 3A, B). Early wood tracheids are 33 (17-64) $\mu \mathrm{m}$ in diameter, with thick (4.7 (2.8-6.6) $\mu \mathrm{m})$ walls. Approximately 6 (2-12) series of tracheids are present between the parenchymatic rays.
In radial section, tracheids present circular to polygonal bordered pits arranged predominantly in uniseriate rows. The biseriate and triseriate pitting pattern is also present, but is less common (Fig 3C, D). The pitting pattern of the radial walls of the tracheids is typical of a mixed wood, with $50 \%$ of abietinoidtype and $50 \%$ of araucarioid-type. Pits measure 24 (16-32) $\mu \mathrm{m}$ in diameter, with circular apertures (10 (7-15) $\mu \mathrm{m}$ in diameter). Cross-field regions (Fig. 3E, F, H, I) are characterized by the presence of 8-26 circular pits (5.7 (4.7-6.7) $\mu \mathrm{m}$ in diameter) arranged in 2-4 rows. Pit apertures are obliquely -oriented, slit like, measuring 1.8-4.5 $\mu \mathrm{m}$ in its greater axis.

In tangential section, rays are exclusively uniseriate, 1-9 (median 4, mean 4) cells tall (Fig. $3 \mathrm{G})$. Ray cells are parenchymatic and measure 73 (44-102) $\mu \mathrm{m}$ in height and 13-57 $\mu \mathrm{m}$ in width. Generally 20 (10-30) rays per $\mathrm{mm}^{2}$ are observed.

Comparisons: The studied specimens are comparable with Brachyoxylon boureaui Serra 1966 identified from the Late Jurassic Phu Kradung Formation in Thailand and coeval units in Cambodia (Serra 1966, Philippe et al. 2004b). This species is characterized by a high (up to 37) number of pits per cross fields, mostly uniseriate radial pitting of the tracheids, and low rays, features shared with the Baqueroan specimens. Based on spatial and temporal differences, we prefer to refer our specimens to Brachyoxylon boureaui with reserves.

Affinities: Brachyoxylon type of wood has been found in association with conifer leaves and Classopollis-bearing cones (Zhou 1983), suggesting that this xylotype is closely related to the Cheirolepidiaceae, a group of plants already identified in Baqueroan strata (e.g. Archangelsky 2003).

\section{CONCLUSIONS}

In this work, the number of taxa reported for the Baqueró Groups is expanded with the description of Brachyoxylon sp. cf. B. boureaui and Agathoxylon sp.. They represent the first fossil woods described 
for the Baqueroan deposits, although the presence of wood had been reported previously in the literature. Agathoxylon sp., characterized by the presence of predominantly uniseriate pitting on the radial walls of the tracheids and one to six pits per cross field, could be adscribed to Araucaria grandifolia Feruglio emend. Del Fueyo and Archangelsky, previously reported as impressions/ compressions of leafy branches. On the other hand, Brachyoxylon sp. cf. B. boureaui represents one of the scarce records of this genus in South America (Philippe et al. 2004a, Gnaedinger et al. 2009) and provides new information about the presence of this xylotype in the Mesozoic of Western Gondwana.

\section{ACKNOWLEDGMENTS}

The authors wish to express their gratitude to Drs. Oscar Limarino, Magdalena Llorens, Mauro Passalía and Valeria Perez Loinaze for their invaluable help in the field. Dr. Marc Philippe kindly provided helpful information regarding taxonomic aspects of fossil woods. Dr. Douglas Riff kindly translated the abstract to Portuguese. The comments made by three anonymous reviewers improved the quality of the paper. Thanks are extended to Lic. Fabián Tricárico, who assisted with SEM photographs at the MACN. This work is a contribution to the PICT 32320 and PIP 512.

\section{RESUMO}

Duas novas morfoespécies de coníferas representadas por xilema secundário são reportadas para o Cretáceo Inferior do Grupo Baqueró (Província de Santa Cruz, Argentina). Agathoxylon sp. é caracterizada por anéis de crescimento poucos definidos, sulcos predominantemente uniseriados na parede radial dos traqueídeos, campos de cruzamento com 1-6 perfurações e raios uniseriados. Estas características são comuns com os ramos frondosos descritos para a unidade como Araucaria grandifolia Feruglio emend. Del Fueyo e Archangelsky. O segundo taxon, Brachyoxylon sp. cf. B. boureaui, possui anéis de crescimento poucos definidos, lenho misto com predominância de sulcos radiais uniseriados, campos de cruzamento com 8-26 perfurações e raios uniseriados. Estes táxons representam a primeira descrição de madeira fóssil para o Grupo Baqueró.

Palavras-chave: Madeiras fossis, Agathoxylon, Brachyoxylon, Cretáceo Inferior, Patagonia, Grupo Baqueró.

\section{REFERENCES}

ARCHANGELSKY S. 1966. New Gymnosperms from the Ticó Flora, Santa Cruz Province, Argentina. Bull Brit Mus (Nat Hist), Geol 13: 259-295.

ARCHANGELSKY S. 1967. Estudio de la Formación Baqueró, Cretácico Inferior de Santa Cruz, Argentina. Rev Mus La Plata, nueva serie 5: 63-171.

ARCHANGElSKY S. 2003. Flora Cretácica del Grupo Baqueró. Monogr Mus Argentino Cienc Nat 4: 1-16 + CD.

ARCHANGELSKY S AND DEL FUeYo G. 1989. Squamastrobus gen. n., a fertile podocarp from the Early Cretaceous of Patagonia, Argentina. Rev Palaeobot Palynol 59: 109-126.

BAMFORD M AND PHILIPPE M. 2001. Jurassic-Early Cretaceous Gondwanan homoxylous woods: a nomenclatural revision of the genera with taxonomic notes. Rev Palaeobot Palynol 113: 287-297.

CÉSARi SN, Limarino CO, Llorens M, Passalia MG, Perez LOINAZE V AND VERA EI. 2011. High-precision late Aptian $\mathrm{U} / \mathrm{Pb}$ age for the Punta del Barco Formation (Baqueró Group), Santa Cruz Province, Argentina. J South Am Earth Sci 31(4): 426-431.

Cladera G, Andreis R, ARChangelsky S AND CÚNeO R. 2002. Estratigrafía del Grupo Baqueró, Patagonia (Provincia de Santa Cruz, Argentina). Ameghiniana 39(1): 3-20.

Corbella H. 2001. Tuffs of the Baqueró Group and the Mid-Cretaceous frame, Extraandean Patagonia, Argentina. In: XI Congreso Latinoamericano de Geología y III Congreso Uruguayo de Geología, Montevideo, Uruguay. Work n. 190, 6 p. (in CD).

Corbella H. 2006. Nuevas determinaciones de edad absoluta para el Grupo Baqueró, Macizo del Deseado, Patagonia Extrandina. In: Actas del $16^{\circ}$ Congreso Geológico Argentino, La Plata, Argentina, p. 69-73.

Del Fueyo G. 1991. Una nueva Araucariaceae cretácica de Patagonia, Argentina. Ameghiniana 28: 149-161.

Del Fueyo GM AND ARChANGElSKY A. 2002. Araucaria grandifolia Feruglio from the Lower Cretaceous of Patagonia. Cret Res 23: 255-267.

Del FueYo GM AND ARChANGELSKY S. 2005. A new Arauca -rian pollen cone with in situ Cyclusphaera Elsik from the Aptian of Patagonia, Argentina. Cret Res 26: 757-768.

DEl Fueyo G, ARChANGELSKY S AND TAYLOR TN. 1990. Una nueva Podocarpácea fértil (Coniferal) del Cretácico Inferior de Patagonia, Argentina. Ameghiniana 27: 63-73. 
Del Fueyo G, Villar de Seoane L, Archangelsky A, GULER V, Llorens M, ARCHANGELSKY S, GAMERro JC, Musacchio EA, Passalia MG AND Barreda VD. 2007. Biodiversidad de las Paleofloras de Patagonia Austral durante el Cretácico Inferior. Asoc Paleont Argentina, Publicación Especial 11: 101-122.

Feruglio E. 1951. Piante del mesozoico della Patagonia. Pubbl Ist Geol Univ Torino 1: 35-80.

GNAEDINGER S, HERBST R AND GOMEZ N. 2009. Brachyoxylon Hollick y Jeffrey, Circoporoxylon Kräusel y Taxaceoxylon Kräusel y Jain del Liásico, provincia de Santa Cruz, Argentina. Ameghiniana 46(4): 122R.

HARTig T. 1848. Beiträge zur Geschichte der Pflanzen und zur Kenntnis der norddeutschen Braunkohlen-Flora. Bot Zeitung (Berlin) 6: 122-128, 137-141, 166-172 y 185-190.

Hollick A AND JefFreY EC. 1909. Studies of coniferous Cretaceous remains from Kreischerville (New-York). Mem N Y Bot Gard 3: 1-137.

Limarino CO, Passalia MG, Llorens M, Vera EI, Perez LOINAZE VS AND CÉSARI SN. 2012. Depositional environments and vegetation of Aptian sequences affected by volcanism in Patagonia. Palaeogeog Palaeoclimatol Palaeoecol 323-325: 22-41.

PHILIPPE M. 1993. Nomenclature générique des trachéidoxyles fossiles mésozoïques à champs araucarioïdes. Taxon 42: 74-80.

PhilipPE M. 1995. Bois fossiles du Jurassique de FrancheComté (nord-est de la France): systématique et biogéographie. Palaeontographica Abt B 236: 45-103.

PHILIPPE M AND BAMFORD MK. 2008. A key to morphogenera used for Mesozoic conifer-like woods. Rev Palaeobot Palynol 148: 184-207.
Philippe M ET AL. 2004a. Biogeographic analysis of JurassicEarly Cretaceous wood assemblages from Gondwana. Rev Palaeobot Palynol 129: 141-173.

Philippe M, Suteethorn V, Lutat P, Buffetaut E, Cavin L, Cuny G AND Barale G. 2004b. Stratigraphical and palaeobiogeographical significance of fossil wood from the Mesozoic Khorat Group of Thailand. Geol Mag 141: 319-328.

PhilipPe M, ZiJlstra G AND BAMFord M. 2002. Proposal to conserve the name Protopodocarpoxylon Eckhold (Fossil, Gymnospermae, Coniferales) with a conserved type. Taxon 51: 207-208.

Poole I AND Mirzaie AtAaBAdi M. 2005. Conifer woods of the Middle Jurassic Hodjek Formation (Kerman Basin) Central Iran. IAWA J 26: 489-505.

SCHIMPER WP. 1870. Traité de Paléontologie végétale ou la Flore du Monde primitif, v. 2. Paris: Bailliére JB et fils, 522 p. +27 pl.

SERRA C. 1966. Etude anatomique et paléogéographique de quelques espèces homoxylées du Sud-Vietnam et du Cambodge. Arch Geol Vietnam 8: 59-131.

SKOG JE. 2003. Report of the Committee for fossil plants: 4 . Taxon 52: 341 .

Villar DE SEOANE L. 1998. Comparative study of extant and fossil conifer leaves from the Baqueró Formation (Lower Cretaceous), Santa Cruz province, Argentina. Rev Palaeobot Palynol 99: 247-263.

Witham HT. 1833. The internal structure of fossil vegetables found in the carboniferous and oolitic deposits of Great Britain. Edinburgh: A \& C Black, 84 p. +16 pl.

ZHOU Z. 1983. A heterophyllous conifer from the Cretaceous of east China. Palaeontol 26: 789-811. 